\title{
Ontogeny, allometry and architecture of Psychotria tenuinervis (Rubiaceae)
}

\author{
Vanessa Rosseto ${ }^{1,2}$, Magda Silva Carneiro ${ }^{3}$, Flavio Nunes Ramos ${ }^{3,4}$ and Flavio Antonio Maës dos Santos
}

Received: 10 May, 2013. Accepted: 19 July, 2013

\begin{abstract}
We evaluated the ontogeny of the understory shrub Psychotria tenuinervis Müll.Arg., considering morphological and morphometric characters. Four ontogenetic stages were identified: seedling, juvenile, immature and adult (vegetative and reproductive phases). Size measurements and allometric relationships of the stem and crown were compared between the immature and adult stages. Diameter and total height of the stem, as well as crown depth and width, increased throughout the ontogenetic stages and differed among immature, vegetative adult and reproductive adult individuals. The number of branches was lower in immature individuals than in vegetative and reproductive adult individuals but did not differ between the last two. The bifurcation ratio did not vary during ontogenetic development. In general, allometric relationships between the stem and the crown were similar among the ontogenetic stages. Although there was a progressive increase in size during ontogenetic development, there was no change in the allometric relationships between the size variables and architecture of P. tenuinervis, indicating that the form of individuals does not change over the course of ontogeny.
\end{abstract}

Key words: allometry, architecture, branching pattern, ontogenetic stages, understory

\section{Introduction}

In population biology studies, age, developmental stage and size can be used, either separately or in combination, to categorize plants (Begon et al. 1996; Silvertown \& Lovett-Doust 1993). The sequence of developmental phases of an individual is called ontogeny (Gatsuk et al. 1980). The average duration of the ontogenetic stages of each species is genetically fixed. However, given that environmental conditions can vary greatly, different individuals can reach certain ontogenetic stages at different times (Gatsuk et al. 1980). Therefore, the study of ontogenetic stages in plant populations supplies much more information with ecological meaning than does the study of age and the size of structures (Silvertown \& Lovett-Doust 1993).

Structural differences during ontogenetic development in different plant groups involve the presence/absence of cotyledons, ramification patterns, stem type, stipe, reproductive structures, and the root system (Souza et al. 2000, 2003; Lienert \& Fischer 2003; Logofet et al. 2006; Miranda-Melo et al. 2007; Bernacci et al. 2008; Fidelis et al. 2008; Schmucki \& de Blois 2009). Morphological changes during ontogenetic development can be evaluated through the study of plant architecture (Bell 1991; Barthélémy \& Caraglio
2007), which describes the inherited branching pattern of species, such as their characteristics related to the direction of growth, activity in time and destiny (Barthélémy \& Caraglio 2007; León Enriquez et al. 2008).

Morphometric characteristics, such as stem and crown size, and allometry have been used to facilitate the characterization and delineation of ontogenetic stages (Souza et al. 2000; 2003). The allometric relationship between height and stem diameter indicates the amount of support that the plant requires within given environmental conditions (Claussen \& Maycock 1995). Morphometric characteristics include total height; stem diameter; number and size of the leaves; rosette diameter; and number of branches (Souza et al. 2000, 2003; Lienert \& Fischer 2003; Logofet et al. 2006; Miranda-Melo et al. 2007; Bernacci et al. 2008; Fidelis et al. 2008; Schmucki \& de Blois 2009).

Plant ontogeny studies have been carried out with palms (Souza et al. 2000, 2003; Bernacci et al. 2008) and herbaceous species (Lienert \& Fisher 2003; Logofet et al. 2006; Fidelis et al. 2008, Schmucki \& de Blois 2009). However, there have been few studies on shrub and tree species (Gatsuk et al. 1980; Miranda-Melo et al. 2007). Due to its dominance in the tropical and subtropical forest understory, the genus Psychotria has been used as a model to infer

\footnotetext{
${ }^{1}$ Universidade Estadual de Campinas, Instituto de Biologia, Departamento de Biologia Vegetal, Campinas-SP, Brazil

${ }^{2}$ Universidade Federal do Pampa, Bagé, RS, Brazil

${ }^{3}$ Universidade Federal de Alfenas, Laboratório de Ecologia de Fragmentos Florestais Alfenas, MG, Brazil

${ }^{4}$ Author for correspondence: fnramos@gmail.com
} 
patterns of speciation (Hamilton 1989); the specialization of habitats (Kinupp \& Magnusson 2005); the association between crown architecture and light capture efficiency (Pearcy et al. 2004); and the plastic phenotypic response to light (Valladares et al. 2000).

The aim of this study was to identify and describe the ontogenetic stages of the shrub Psychotria tenuinervis Müll. Arg. and evaluate changes in individual size, allometry and architecture during ontogenetic development. Because P. tenuinervis is a shade-tolerant shrub species, we expected differences during ontogenetic development, mainly related to architecture, given that species adapted to low-light conditions have a crown that is wide in order to intercept light over a large area and shallow in order to minimize self-shading (Givnish 1988).

\section{Materials and methods}

\section{Study site and species}

This study was carried out in the Serra de Palmital coastal mountain range, near the municipality of Saquarema, in southeastern Brazil. The study site ( $\left.22^{\circ} 50^{\prime} \mathrm{S} ; 42^{\circ} 28^{\prime} \mathrm{W}\right) \mathrm{com}$ prised 1200 ha of Atlantic Forest at an elevation of 30-400 m. According to the Köppen system of classification, the climate is type Cwa (Veanello \& Alvez 1991), defined as warm (up to $18^{\circ} \mathrm{C}$ ) and semi-humid (with 4-6 dry months per year). In 2003, minimum and maximum monthly temperatures ranged from $12.6^{\circ} \mathrm{C}$ to $19.0^{\circ} \mathrm{C}$ and $23.8^{\circ} \mathrm{C}$ to $34.2^{\circ} \mathrm{C}$ respectively (Ramos \& Santos 2006). The vegetation in the study area is evergreen forest, with 39 families and 132 morphospecies sampled in a 0.75 ha area (Ribeiro et al. 2009).

Rubiaceae has a pantropical distribution, comprising approximately 550 genera and 9000 species (Souza \& Lorenzi 2005). Psychotria is the largest genus in Rubiaceae, with approximately 2000 species (Davis et al. 2001), and contains mainly shrubs and small trees, which are dominant in the tropical and subtropical forest understory (Hamilton 1990; Valladares et al. 2000). Psychotria tenuinervis is a shrub that reaches 1-5 m height, endemic to fragments of Atlantic Forest in the state of Rio de Janeiro, and common in the understory (Gomes et al. 1995). Flowers are produced within 1-3 months, whereas the fruiting lasts for 3-6 months per year (Ramos \& Santos 2005). Vegetative growth has been observed for a few individuals of $P$. tenuinervis.

\section{Data collection}

In order to characterize the ontogenetic stages of Psychotria tenuinervis individuals (Gatsuk et al. 1980), we registered the presence/absence of cotyledons, ramifications and reproductive structures, such as flowers and fruits. We also registered the total height and diameter at ground level of immature and adult individuals. To evaluate the architectural pattern of immature and adult individuals, we measured the fork height, crown diameter (east-west and north-south cross sections), total number of branches, crown depth, crown width, and bifurcation ratio. Individuals were monitored for a period of 18 months.

Fork height was defined as the vertical distance between the stem base and lowest major branch, which itself is defined as a branch that is at least half as thick as the main stem at the same height (Osunkoya et al. 2007). Crown depth was calculated as the difference between total height and fork height (Osunkoya et al. 2007). Crown width was determined as the average diameter of the east-west and north-south cross sections of the crown (Poorter et al. 2003).

To evaluate the number of branches, the branches were ordered, with each terminal branch designated the first order (Strahler 1957, cited in Steingraeber et al. 1979, Sposito \& Santos 2001a). Where two first-order branches met, the resulting segment was designated the second order. For the meeting of two branches of unequal order, the resulting branch retained the name of the class of the next-highest order. Therefore, the stem would be the class of higher order for the plant. The bifurcation ratio was calculated with the Motomura formula (Motomura 1947, cited in Steingraeber et al. 1979):

$$
B r=\left(N-N_{\max }\right) /\left(N-N_{1}\right)
$$

where $B r$ is the bifurcation ratio; $N$ is the total number of branches; $N_{\max }$ is the number of higher-order branches, and $N_{1}$ is the number of first-order branches.

\section{Statistical analysis}

After testing for normality and homoscedasticity (Zar 1996), we used ANOVA to compare morphometric characters among ontogenetic stages. Analyses were performed with the Systat program, version 10.2 (SPSS 2000).

For each ontogenetic stage, we compared the allometric relationships between total height and diameter at ground level using ANCOVA, in which the angular and linear coefficients of each regression analysis are compared. When the difference was significant, we used post hoc Scheffé tests through the program Ancova33 (Santos 1997).

\section{Results}

\section{Ontogenetic stages}

On the basis of the morphological and morphometric characteristics observed over the 18-month study period, we defined the four ontogenetic stages for Psychotria tenuinervis:

$>$ Seedling (Fig. 1a) - In the seedling stage, the cotyledons are green or dry and are darker than are the other leaves. Some individuals exhibit cotyledons with a whitish color along the midrib. Some seedlings present one or more pairs of opposing primary leaves, without stem ramification. Growth is monopodial, and the stem can be lignified or not. 
$>$ Juvenile (Fig.1b) - In the juvenile stage, there are no cotyledons, growth is monopodial, and the stem has no branches. Some individuals present flexible, green stems, whereas others have woody stems, especially near the base.

$>$ Immature (Fig. 1c) - In the immature stage, growth is sympodial and the stem is fully lignified, with orthotropic and plagiotropic branches. The total height is $<1 \mathrm{~m}$.

$>$ Adult (Fig. 1d and 1e) - In the adult stages, growth is sympodial and the stem has orthotropic and plagiotropic branches. The total height is $\geq 1 \mathrm{~m}$. This stage was divided into two phases:

- Vegetative (Fig. 1d) - In the vegetative adult phase, individuals present no flowers or fruits.

- Reproductive (Fig. 1e and 1f) - In the vegetative adult phase, individuals present flowers, fruits or both.

Leaf shape was similar among the ontogenetic stages (Fig. 1). Analyses of morphometric data showed that total height, diameter at ground level, crown depth and crown wi$\mathrm{dth}$ increased during ontogenetic development and differed among immature, vegetative adult and reproductive adult individuals (Tab. 1; Fig. 2). Individuals presented between 3 and 2020 first- to seventh-order branches. Although immature individuals showed fewer branches than did vegetative and reproductive adult individuals, there was no difference between vegetative and reproductive adults in terms of the number of branches (Tab. 1; Fig. 2). The bifurcation ratio did not vary during ontogenetic development (Tab. 1; Fig. 2).
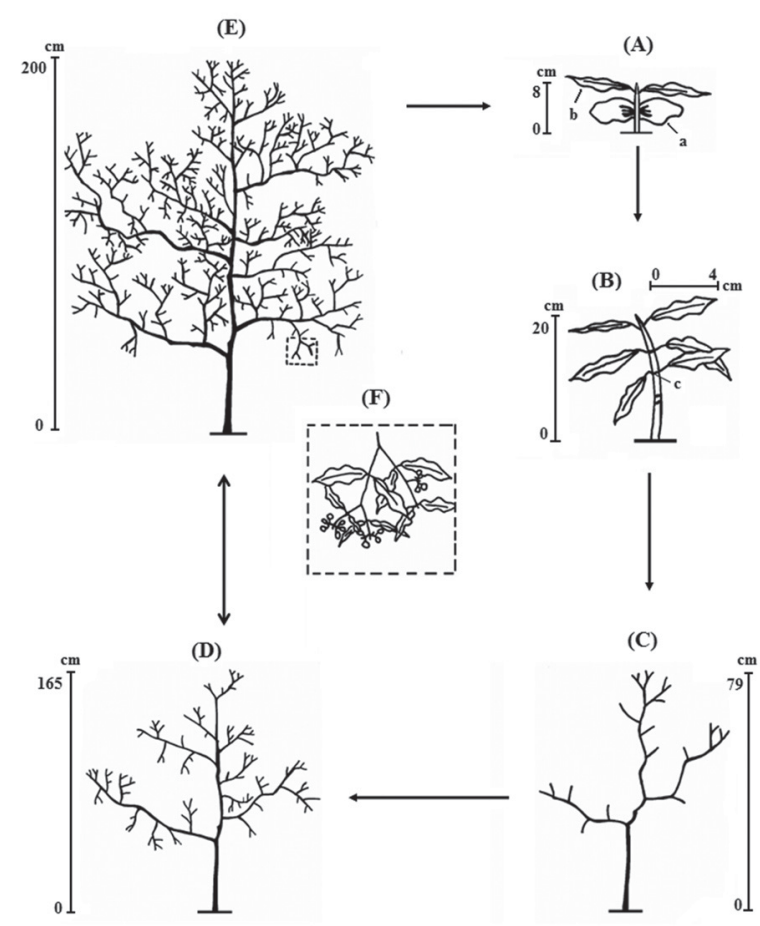

Figure 1. Schematic representation of the ontogenetic stages of Psychotria tenuinervis Müll.Arg.: (A) seedling; (B) juvenile; (C) immature; (D) adult (vegetative phase); and (E) adult (reproductive phase). In F, detail of branch with fruit. $\mathrm{a}$ - cotyledon; $\mathrm{b}$ - primary leaves; $\mathrm{c}$ - unbranched stem.

\section{Stem and crown relationships}

In general, the relationships between the stem and crown remain constant during ontogenetic development in Psychotria tenuinervis. Linear regression analyses revealed that nearly all of the associations between the crown and stem parameters were significant $(p<0.001)$, the exception being the relationship between the number of branches and crown depth in reproductive adults (ANOVA: $\mathrm{F}_{1,13}=2.70, \mathrm{p}=0.12$ ).

No significant differences were found among the immature and adult stages (vegetative and reproductive phases) in terms of the relationship between stem diameter and total height, neither for the angular coefficient (ANCOVA: $\mathrm{F}_{2,72}=0.15, \mathrm{p}=0.86$; Tab. 2) nor for the linear coefficient (intercept; ANCOVA: ${ }_{\mathrm{F} 2,74}=0.20, \mathrm{p}=0.82$; Tab. 2).

The relationship between total height and crown depth did not differ among immature, vegetative and reproductive adult individuals, for the angular coefficient (ANCOVA: $\mathrm{F}_{2,74}=3.69, \mathrm{p}=0.03$; Tab. 2), whereas the linear coefficient differed significantly between immature and reproductive adult individuals (ANCOVA: $\mathrm{F}_{1,53}=5.79, \mathrm{p}=0.02$; Tab. 2 ), but not between vegetative and reproductive adult individuals (ANCOVA: $\mathrm{F}_{1,46}=0.51, \mathrm{p}=0.49$; Tab. 2). This suggests that crown depth increases in parallel with the increase in total height during the immature stage. The relationship between total height and crown width did not differ between ontogenetic stages for the angular coefficient (ANCOVA: $\mathrm{F}_{2,74}=0.004, \mathrm{p}=0.99, \mathrm{~b}=0.76$; Tab. 2) or the linear coefficient (ANCOVA: $\mathrm{F}_{2,76}=0.008, \mathrm{p}=0.98 ; \mathrm{a}=-0.23$; Tab. 2).

The relationship between total height and the number of branches did not differ during ontogenetic development, for the angular coefficient (ANCOVA: $\mathrm{F}_{2,54}=2.11, \mathrm{p}=0.13$, common $b=2.18$; Tab. 2) or the linear coefficient (ANCOVA: $\mathrm{F}_{2,56}=0.39, \mathrm{p}=0.68$, common $\mathrm{a}=1.96 ;$ Tab. 2)

The angular coefficient for the relationship between the number of branches and crown depth differed between immature and vegetative adult individuals (ANCOVA: $\mathrm{F}_{2,54}=14.37, \mathrm{p}<0.001 ;$ Tab. 2). The angular coefficient for the relationship between the number of branches and crown width differed only between immature and vegetative adult individuals (ANCOVA: $\mathrm{F}_{2,54}=3.68, \mathrm{p}=0.03$; Tab. 2). The linear coefficient for that same relationship differed between immature and reproductive adult individuals (ANCOVA: $\mathrm{F}_{1,42}=0.66, \mathrm{p}=0.43$; Tab. 2 ) but not between vegetative and reproductive adults (ANCOVA: $\mathrm{F}_{1,27}=2.69, \mathrm{p}=0.11$; Tab. 2 ).

\section{Discussion}

\section{Ontogenetic stages}

The overlap of some measurements of size and allometric relationships among immature, vegetative and reproductive adult individuals indicates that size does not always correspond to individual age. Hence, individuals of the same size may be at different ontogenetic stages and 
Table 1. Morphometric characteristics of Psychotria tenuinervis Müll.Arg. (immature and adult individuals), in a fragment of Atlantic Forest in the Serra de Palmital coastal mountain range of southeastern Brazil.*

\begin{tabular}{|c|c|c|c|c|c|c|c|}
\hline \multirow{2}{*}{$\begin{array}{l}\text { Ontogenetic stage } \\
(\mathrm{m})\end{array}$} & & Height & Diameter & Crown depth & Crown width & \multirow{2}{*}{$\begin{array}{c}\text { Number of } \\
\text { branches }\end{array}$} & \multirow{2}{*}{$\begin{array}{l}\text { Bifurcation } \\
\text { ratio }\end{array}$} \\
\hline & & $(\mathrm{cm})$ & $(\mathrm{m})$ & $(\mathrm{m})$ & & & \\
\hline \multirow{3}{*}{ Immature } & range & $0.16-0.99$ & $0.08-1.29$ & $0.01-0.99$ & $0.13-0.71$ & $3-200$ & $2.00-4.00$ \\
\hline & mean & $0.51^{\mathrm{a}}$ & $0.53^{\mathrm{a}}$ & $0.37^{\mathrm{a}}$ & $0.35^{\mathrm{a}}$ & $36.33^{\mathrm{a}}$ & $3.05^{\mathrm{a}}$ \\
\hline & $\mathrm{n}$ & 31 & 31 & 31 & 31 & 30 & 30 \\
\hline \multicolumn{8}{|l|}{ Adult } \\
\hline \multirow{3}{*}{ Vegetative phase } & range & $1.13-3.05$ & $0.94-3.98$ & $0.67-2.48$ & $0.53-2.00$ & 38-1962 & $2.63-3.45$ \\
\hline & mean & $1.75^{\mathrm{b}}$ & $1.72^{\mathrm{b}}$ & $1.23^{\mathrm{b}}$ & $0.92^{\mathrm{b}}$ & $481.93^{\mathrm{b}}$ & $3.02^{\mathrm{a}}$ \\
\hline & $\mathrm{n}$ & 24 & 24 & 24 & 24 & 15 & 15 \\
\hline \multirow{3}{*}{ Reproductive phase } & range & $1.05-4.40$ & $0.85-4.46$ & $0.69-4.22$ & $0.58-2.15$ & $126-2020$ & $2.71-3.48$ \\
\hline & mean & $2.53^{c}$ & $2.43^{\mathrm{c}}$ & $1.96^{\mathrm{c}}$ & $1.22^{\mathrm{c}}$ & $742.80^{\mathrm{b}}$ & $3.01^{\mathrm{a}}$ \\
\hline & $\mathrm{n}$ & 25 & 23 & 25 & 25 & 15 & 15 \\
\hline \multirow{2}{*}{ ANOVA } & distribution & $\mathrm{F}_{2,77}=91.41$ & $\mathrm{~F}_{2,75}=49.92$ & $\mathrm{~F}_{2,77}=57.98$ & $\mathrm{~F}_{2,77}=64.35$ & $\mathrm{~F}_{2,57}=16.59$ & $\mathrm{~F}_{2,57}=0.07$ \\
\hline & $\mathrm{p}$ & 0.000 & 0.000 & 0.000 & 0.000 & 0.000 & 0.932 \\
\hline
\end{tabular}

${ }^{*}$ Means sharing the same letter within a column do not differ significantly (ANOVA and Tukey's test).
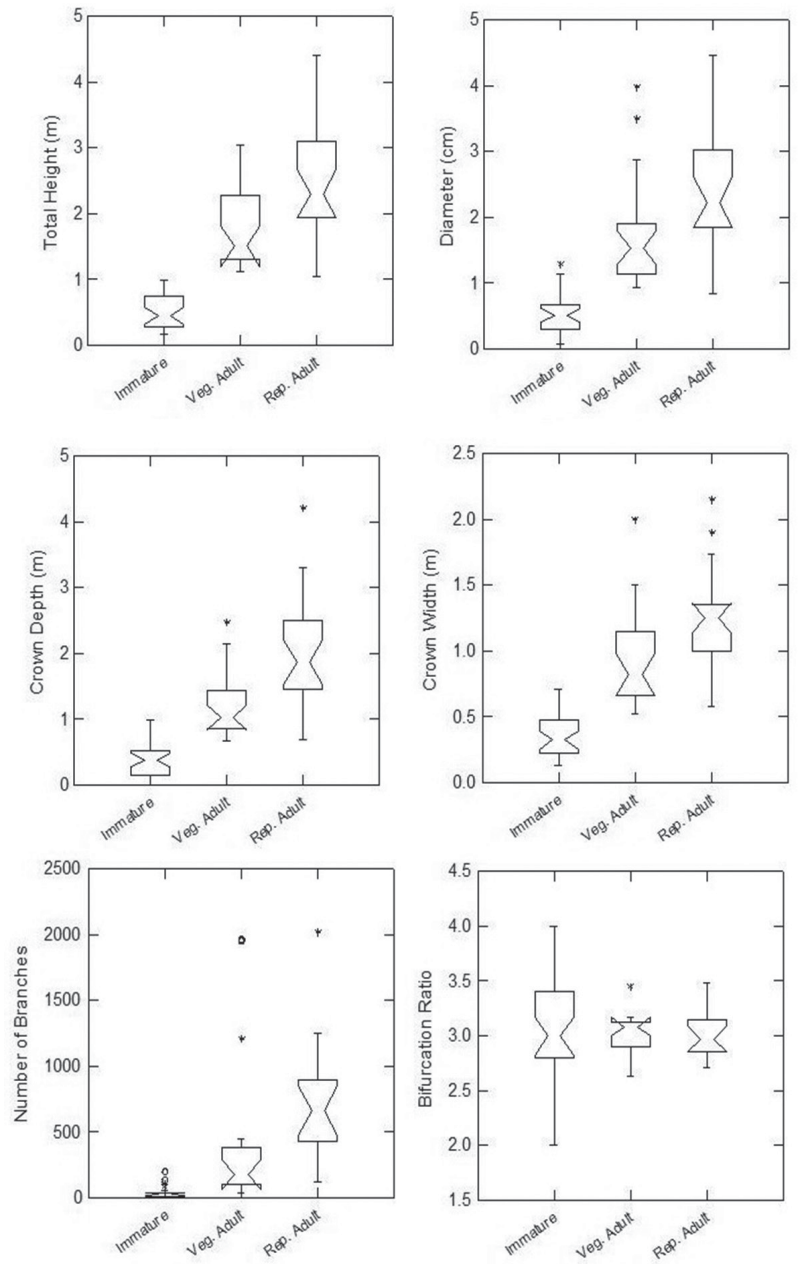

Figure 2. Box-plot of morphometric characters for the ontogenetic stages of Psychotria tenuinervis Müll.Arg. The length of each box encompasses the two central quartiles (50\% of the central values), in which the narrowest part of the box represents the median and the narrowing region is the confidence interval (McGill et al. 1978). Asterisks and circles are outliers. Where confidence intervals overlap, the median is equal between the stages.

A-vp - Adult-vegetative phase; A-rp - Adult-reproductive phase. may differ in terms of their use of environmental resources at a given time and in a given space (Gatsuk, et al. 1980). The identification and characterization of the ontogenetic stages of Psychotria tenuinervis is partly consistent with the classification system devised by Gatsuk et al. (1980): seed, seedling, juvenile, immature, virginile, reproductive (young, mature, old), subsenile and senile.

Seedlings have cotyledons, characteristically with partial heterotrophic nutrition showing vestiges of embryonic structures (Gatsuk et al. 1980). We found that, during the 18 months of our study period, Psychotria tenuinervis seedlings showed low density in comparison with the subsequent stages (Rosseto et al., unpublished data). In a study of eight Psychotria species, Paz \& Martínez-Ramos (2003) found that, at two months after emergence, individuals no longer presented cotyledons and developed a pair of true leaves, indicating that the seedling stage is ephemeral in this genus.

Juveniles presented monopodial growth and stems without embryonic structures, although the leaf shape remained similar in the subsequent stages. In Psychotria tenuinervis, the change from monopodial to sympodial growth occurs at the immature stage and is likely associated with greater lignification of the stem, resulting in improved resistance. The immature stage can be characterized by considerable growth, in terms of the total height and the crown parameters, especially crown depth.

It was necessary to use a size descriptor in order to differentiate between the pre-reproductive and reproductive stages in Psychotria tenuinervis, because of the lack of visible macro-morphological markers. In addition, because no permanent reproductive markers were found, it was necessary to adapt the classification of Gatsuk et al. (1980) by creating an adult ontogenetic stage (vegetative and reproductive phases). The vegetative adult phase includes the pre-reproductive, reproductive and post-reproductive periods because it includes individuals who did not reproduce, individuals who already have reproduced, and senile 
Table 2. Linear regressions $\left(\log _{10}\right)$ and statistical parameters for morphometric characteristics of Psychotria tenuinervis Müll.Arg. (immature and adult individuals), in a fragment of Atlantic Forest in the Serra de Palmital coastal mountain range of southeastern Brazil.*

\begin{tabular}{|c|c|c|c|c|c|c|}
\hline Comparison & \multirow{2}{*}{$\mathrm{b}$} & \multirow{2}{*}{ SE1 } & \multirow{2}{*}{$a$} & \multirow{2}{*}{ SE2 } & \multirow{2}{*}{$r^{2}$} & \multirow{2}{*}{$\mathrm{N}$} \\
\hline Ontogenetic stage & & & & & & \\
\hline \multicolumn{7}{|l|}{ Height vs. Diameter } \\
\hline Immature & $1.01^{\mathrm{a}}$ & \pm 0.12 & $-0.01^{\mathrm{b}}$ & \pm 0.05 & 0.71 & 31 \\
\hline \multicolumn{7}{|l|}{ Adult } \\
\hline Vegetative phase & $1.03^{\mathrm{a}}$ & \pm 0.19 & $-0.03^{\mathrm{b}}$ & \pm 0.05 & 0.58 & 24 \\
\hline Reproductive phase & $1.14^{\mathrm{a}}$ & \pm 0.17 & $-0.06^{\mathrm{b}}$ & \pm 0.07 & 0.68 & 23 \\
\hline \multicolumn{7}{|l|}{ Height vs. Crown Depth } \\
\hline Immature & $1.79^{\mathrm{a}}$ & \pm 0.24 & $0.01^{\mathrm{a}}$ & \pm 0.10 & 0.66 & 31 \\
\hline \multicolumn{7}{|l|}{ Adult } \\
\hline Vegetative phase & $0.98^{\mathrm{a}}$ & \pm 0.12 & $-0.16^{\mathrm{b}}$ & \pm 0.03 & 0.74 & 24 \\
\hline Reproductive phase & $1.14^{\mathrm{a}}$ & \pm 0.15 & $-0.18^{\mathrm{b}}$ & \pm 0.06 & 0.72 & 25 \\
\hline \multicolumn{7}{|l|}{ Height vs. Crown Width } \\
\hline Immature & $0.77^{\mathrm{a}}$ & \pm 0.08 & $-0.23^{\mathrm{b}}$ & \pm 0.04 & 0.74 & 31 \\
\hline \multicolumn{7}{|l|}{ Adult } \\
\hline Vegetative phase & $0.76^{\mathrm{a}}$ & \pm 0.16 & $-0.23^{\mathrm{b}}$ & \pm 0.04 & 0.51 & 24 \\
\hline Reproductive phase & $0.76^{\mathrm{a}}$ & \pm 0.10 & $-0.22^{\mathrm{b}}$ & \pm 0.04 & 0.70 & 25 \\
\hline \multicolumn{7}{|l|}{ Height vs. Number of Branches } \\
\hline Immature & $2.01^{\mathrm{a}}$ & \pm 0.20 & $1.96^{\mathrm{b}}$ & \pm 0.08 & 0.77 & 30 \\
\hline \multicolumn{7}{|l|}{ Adult } \\
\hline Vegetative phase & $3.10^{\mathrm{a}}$ & \pm 0.58 & $1.71^{\mathrm{b}}$ & \pm 0.14 & 0.69 & 15 \\
\hline Reproductive phase & $2.13^{\mathrm{a}}$ & \pm 0.56 & $1.93^{\mathrm{b}}$ & \pm 0.23 & 0.53 & 15 \\
\hline \multicolumn{7}{|c|}{ Number of Branches vs. Crown Depth } \\
\hline Immature & $0.86^{\mathrm{a}}$ & \pm 0.10 & -1.71 & \pm 0.14 & 0.73 & 30 \\
\hline \multicolumn{7}{|l|}{ Adult } \\
\hline Vegetative phase & $0.19^{\mathrm{b}}$ & \pm 0.06 & -0.39 & \pm 0.15 & 0.44 & 15 \\
\hline Reproductive phase & $0.21^{\mathrm{a}}$ & \pm 0.13 & -0.32 & \pm 0.36 & 0.17 & 15 \\
\hline \multicolumn{7}{|c|}{ Number of Branches vs. Crown Width } \\
\hline Immature & $0.36^{a}$ & \pm 0.03 & $-0.96^{\mathrm{a}}$ & \pm 0.04 & 0.86 & 30 \\
\hline \multicolumn{7}{|l|}{ Adult } \\
\hline Vegetative phase & $0.22^{\mathrm{b}}$ & \pm 0.06 & $-0.60^{\mathrm{b}}$ & \pm 0.13 & 0.54 & 15 \\
\hline Reproductive phase & $0.29^{\mathrm{ab}}$ & \pm 0.07 & $-0.73^{\mathrm{ab}}$ & \pm 0.20 & 0.56 & 15 \\
\hline
\end{tabular}

${ }^{*}$ Means sharing the same letter within a column/comparison do not differ significantly (ANCOVA and Scheffé test, $\mathrm{p}=0.05$ ).

b - angular coefficient; SE1 - standard error (angular coefficient); a - linear coefficient; SE2 - standard error (linear coefficient); $\mathrm{r}^{2}$ - coefficient of determination; $\mathrm{N}$ - sample size.

individuals. The reproductive adult phase includes the reproductive and post-reproductive periods. In the adult stage, sexual maturation occurs and there is an increase in the size of the organs, although this does not change the growth pattern in comparison with the pre-reproductive period.

Plant size is an important component of plant fitness, having consequences for survival and fecundity (Harper \& Bell 1979; Weiner \& Thomas 1986). Size is related to fecundity because plants flower and fruit only after reaching a certain size (Harper \& White 1974). A size difference between vegetative and reproductive adults would indicate that energy accumulation is necessary before reproducing, and that this accumulation could only be achieved by an increase in size.

\section{Stem and crown relationships}

Various studies have demonstrated significant differences among ontogenetic stages in terms of stem diameter-height relationships (Niklas 1993; Claussen \& Maycock 1995; O’Brien et al. 1995; Sterck \& Bongers 1998; Sposito \& Santos 2001b; Alves \& Santos 2002; Bohlman \& O’Brien 
2006; Osunkoya et al. 2007). For small-sized understory species, the increase in stem diameter provides the improved mechanical stability needed to survive in the lower strata (Kohyama et al. 2003). However, for Psychotria tenuinervis, no change was observed between immature and adult individuals in terms of the stem diameter-height relationships. This indicates that there is an isometric relationship between those variables, meaning that structures of different sizes have the same shape (Rich et al. 1986). That might be associated with the fact that understory species are less exposed to lateral wind, so that, with a minimal biomass investment in branches, stem diameter is proportional to height (Norberg 1988; Osunkoya et al. 2007).

Some authors have shown that understory tree species have more horizontal expansion of the crown than do other successional groups (King 1990, 1996; Kohyama \& Hotta 1990; Aiba \& Kohyama 1996; Sterck \& Bongers 1998), although others have found the opposite or even no difference (Poorter et al. 2003; Osunkoya et al. 2007). Although Psychotria tenuinervis exhibited a continuous increase in crown parameters (crown depth, crown width and number of branches) during ontogenetic development, we observed no variation among ontogenetic stages in terms of the relationships between height and crown parameters. The relationship between crown depth and crown width remained similar across stages, indicating a symmetrical pattern of crown development. The bifurcation ratio did not change during ontogenetic development, indicating that the addition of new branches follows a branching pattern that apparently remains constant over the life history of $P$. tenuinervis.

In the understory, light availability is highly heterogeneous (Poorter \& Arets 2003, Valladares \& Niinemets 2008). At the study site, canopy openness ranged from $4.0 \%$ to $18.9 \%$, depending on the season (Ramos \& Santos 2006). Strategies of survival, growth and establishment in light gradient among understory species are related to plant size, leaf geometry, crown architecture and position, as well as physiological factors (Valladares et al. 2000; Poorter et al. 2003; Pearcy et al. 2004; Osunkoya et al. 2007). In tropical rainforests of Central America, Psychotria species have less physiological plasticity and lower efficiency of light absorption in canopy gaps and in the understory than do understory species of different taxa (Valladares et al. 2000; Pearcy et al. 2004). The low growth rate, photosynthesis and nutrient absorption seen in Psychotria genus might be a mechanism of tolerance to light stress (Kitajima 1994, Valladares et al. 2000, Valladares \& Niinemets 2008).

In Psychotria tenuinervis, we observed little morphological or allometric variation between ontogenetic stages, indicating that the form of individuals does not change during ontogenetic development. Over the course of ontogenetic development, there was a progressive increase in size, although there was no change in the allometric relationships between size variables and architecture in this species. The persistence of $P$. tenuinervis in the understory might be associated with the minimal structural variations during ontogenetic development, which could be an energy-saving strategy.

\section{Acknowledgments}

The authors thank Maíra Taquiguthi Ribeiro, Carolina Virillo, Élcio and Antônio Rosa, for their help with the fieldwork, as well as Jim Hesson, for correcting the English. This work received financial support from the Fundação de Amparo à Pesquisa do Estado de São Paulo (FAPESP, São Paulo Research Foundation; Grant no. 02/01803-5).

\section{References}

Aiba, S.-I. \& Kohyama, T. 1996. Tree species stratification in relation to allometry and demography in a warm-temperate rain forest. Journal of Ecology 84: 207-218.

Alves, L.F.; Santos \& F.A.M. 2002. Tree allometry and crown shape of four tree species in Atlantic rain Forest, south-east Brazil. Journal of Tropical Ecology 18: 245-260.

Barthélémy, D. \& Caraglio, Y. 2007. Plant architecture: a dynamic, multilevel and comprehensive approach to plant form, structure and ontogeny. Annals of Botany 99: 375-407.

Begon, M.; Harper, J.L. \& Townsend, C.R. 1996. Ecology: individuals, populations, and communities. Oxford, Blackwell Science.

Bell, A.D. 1991. Plant form: an illustrated guide to flowering plant morphology. New York, Oxford University Press.

Bernacci, L.C.; Martins, F.R. \& Santos, F.A.M. 2008. Estrutura de estádios ontogenéticos em população nativa da palmeira Syagrus romanzoffiana (Cham.) Glassman (Arecaceae). Acta Botanica Brasilica 22: 119-130.

Bohlman, S. \& O'Brien, S. 2006. Allometry, adult stature and regeneration requirement of 65 tree species on Barro Colorado Island, Panama. Journal of Tropical Ecology 22: 123-136.

Claussen, J.W. \& Maycock, C.R. 1995. Stem allometry in a North Queensland tropical rain forest. Biotropica 4: 421-426.

Davis, A.P.; Bridson, D.; Jarvis, C. \& Govaerts, R. 2001. The typification and characterization of genus Psychotria L. (Rubiaceae). Botanical Journal of the Linnean Society 135: 35-42.

Fidelis, A.; Overbeck, G.; Pillar, V.D. \& Pfadenhauer, J. 2008. Effects of disturbance on population biology of the rosette species Eryngium horridum Malme in grasslands in southern Brazil. Plant Ecology 195: 55-67.

Gatsuk, L.E.; Smirnova, O.V.; Vorontzova, L.I.; Zaugolnova, L.B. \& Zhukova, L.A. 1980. Age states of plants of various growth forms: a review. Journal of Ecology 68: 675-696.

Givnish. T.J. 1988. Adaptation to sun and shade, a whole-plant perspective. Australian Journal of Plant Physiology 15: 63-92.

Gomes, D.M.S.; Mantovani, A. \& Vieira, R. C. 1995. Anatomia foliar de Psychotria tenuinervis Muell. Arg. e Psychotria stenocalix Muell. Arg. (Rubiaeceae). Brazilian Archives of Biology and Technology 38: 15-33.

Hamilton, C.W. 1989. A revision of Mesoamerican Psychotria subg. Psychotria (Rubiaceae). Part 1: introduction and species. Annals of the Missouri Botanical Garden 76: 67-111.

Hamilton, C.W. 1990. Variations in a distylous theme in mesoamerican Psychotria subgenus Psychotria (Rubiaceae). Memories of The New York Botanical Garden 55: 62-75.

Harper, J.L. \& Bell, A.D. 1979. The population dynamics of growth form in organisms with modular construction. Pp. 29-52. In: Anderson, R.M., Turner, B.D., Taylor, L.R. (Eds.). Population dynamics. Oxford, Blackwell.

Harper, J.L. \& White, J. 1974. The demography of plants. Annual Review of Ecology and Systematics 5: 419-463. 
King, D.A. 1990. Allometry of saplings and understorey trees of a Panamanian forest. Functional Ecology 4: 27-32.

King, D.A. 1996. Allometry and life history of tropical trees. Journal of Tropical Ecology 12: 25-44.

Kinupp, V.F. \& Magnusson, W.E. 2005. Spatial patterns in the understorey shrub genus Psychotria in central Amazonia: effects of distance and topography. Journal of Tropical Ecology 21: 363-374.

Kitajima, K. 1994. Relative importance of photosynthetic traits and allocation patterns as correlates of seedling shade tolerance of 13 tropical trees. Oecologia 98: 419-428.

Kohyama, T. \& Hotta, M. 1990. Significance of allometry in tropical saplings. Functional Ecology 4: 515-521.

Kohyama, T.; Suzuki, E.; Mihardjo, T.; Yamada, T. \& Kubo, T. 2003. Tree species differentiation in growth, recruitment and allometry in relation to maximum height in a Bornean mixed dipterocarp forest. Journal of Ecology 91: 797-806.

León Enriquez, B.L.; Vester, H.F.M. \& Hallé, F. 2008. The architecture of Phyllanthus acuminatus Vahl: a prelude to understanding the architectural evolution in the Phyllanthaceae. Adansonia 30: 137-149.

Lienert, J. \& Fischer, M. 2003. Habitat fragmentation affects the common wetland specialist Primula farinosa in North-East Switzerland. Journal of Ecology 91: 587-599.

Logofet, D.O.; Ulanova, N.G.; Klochkova, I.N. \& Demidova, A.N. 2006. Structure and dynamics of a clonal plant population: classical model results in a non-classic formulation. Ecological Modelling 192: 95-106.

McGill, R.; Tukey, J.W. \& Larsen, W.A. 1978. Variations of box plots. Journal of the American Statistical Association 32: 12-16.

Miranda-Melo, A.A.; Martins, F.R. \& Santos, F.A.M. 2007. Estrutura populacional de Xylopia aromatica (Lam.) Mart. e de Roupala montana Aubl. em fragmentos de cerrado no estado de São Paulo. Revista Brasileira de Botânica 30: 501-507.

Niklas, K.J. 1993. The scaling of plant height: a comparison among major plant clades and anatomical grades. Annual of Botany 72: 165-172.

Norberg, R.A. 1988. Theory of growth geometry and self-thinning of plant populations: geometric similarity, elastic similarity, and different growth modes of plant parts. American Naturalist 131: 220-256.

O'Brien, S.T.; Hubbell, S.P.; Spiro, P.; Condit \& Foster, R.B. 1995. Diameter, height, crown and age relationships in eight neotropical tree species. Ecology 76: 1926-1939.

Osunkoya, O.O.; Omar-Ali, K.; Amit, N.; Dayan, J.; Daud, D.S. \& Sheng, T.K., 2007. Comparative height-crown allometry and mechanical design in 22 tree species of Kuala Belalong rainforest, Brunei, Borneo. American Journal of Botany 94: 1951-1962.

Paz, H. \& Martínez-Ramos, M. 2003. Seed mass and seedling performance within eight species of Psychotria (Rubiaceae). Ecology 84: 439-450.

Pearcy, R.W.; Valladares, F.; Wright, S.J. \& de Paulis, E.L., 2004. A functional analysis of the crown architecture of tropical forest Psychotria species: do species vary in light capture efficiency and consequently in carbon gain and growth? Oecologia 139: 163-177.

Poorter, L.; Bongers, F.; Sterck, F.J. \& Wöll, H. 2003. Architecture of 53 rain forest tree species differing in adult stature and shade tolerance. Ecology 84: 602-608.

Poorter, L. \& Arets, E.J.M.M. 2003. Light environment and tree strategies in a Bolivian tropical moist forest: an evaluation of the light partitioning hypothesis. Plant Ecology 166: 295-306.
Ramos, F.N. \& Santos, F.A.M. 2005. Phenology of Psychotria tenuinervis (Rubiaceae) in Atlantic forest fragments: fragment and habitat scales. Canadian Journal of Botany 83: 1305-1316.

Ramos, F.N. \& Santos, F.A.M. 2006. Microclimate of Atlantic forest fragments: regional and local scale heterogeneity. Brazilian Archives of Biology and Technology 49: 935-944.

Ribeiro, M.T.; Ramos, F.N.; Santos, F.A.M. 2009. Tree structure and richness in an Atlantic forest fragment: distance from anthropogenic and natural edges. Revista Árvore 33: 1123-1132.

Rich, M.; Helenurm, K.; Kearns, D.; Morse, S.R.; Palmer, M.W. \& Short, L., 1986. Height and stem diameter relationships for dicotyledonous trees and arborescent palms of Costa Rican tropical wet forest. Journal of the Torrey Botanical Society 113: 241-246.

Santos, F.A.M., 1997. Ancova33: Programa para cálculo de regressão e covariância. Versão 3.3. Departamento de Botânica. Universidade Estadual de Campinas, Campinas.

Schmucki, R. \& de Blois, S. 2009. Population structures and individual performances of Trillium grandiflorum in hedgerow and forest habitats. Plant Ecology 202: 67-78.

Silvertown, J.W. \& Lovett-Doust, J. 1993. Introduction to plant population biology. Oxford, Blackwell Scientific Publications.

Souza, A.F.; Martins, F.R.; Silva-Matos, D.M. 2000. Detecting ontogenetic stages of the palm Attalea humilis in fragments of the Brazilian Atlantic Forest. Canadian Journal of Botany 78: 1227-1237.

Souza, A.F.; Martins, F.R. \& Bernacci, L.C. 2003. Clonal growth and reproductive strategies of the understory tropical palm Geonoma brevispatha: an ontogenetic approach. Canadian Journal of Botany 81: 101-112.

Souza, V.C. \& Lorenzi, H. 2005. Botânica sistemática: guia ilustrado para identificação das famílias de Angiospermas da flora brasileira, baseado em APG II. Nova Odessa, Instituto Plantarum.

Sposito, T.C. \& Santos, F.A.M. 2001a. Architectural patterns of eight Cecropia (Cecropiaceae) species of Brazil. Flora 196: 215-226.

Sposito, T.C. \& Santos, F.A.M. 2001b. Scaling of stem and crown in eight Cecropia (Cecropiaceae) species of Brazil. American Journal of Botany 88: 939-949.

SPSS Inc., 2000. SYSTAT version 10.2, standard version. Chicago, SPSS Inc.

Steingraeber, D.A.; Kascht, L.J. \& Franck, D.H. 1979. Variation of shoot morphology and bifurcation ratio in sugar maple (Acer saccharum) saplings. American Journal of Botany 66: 441-445.

Sterck, F.J. \& Bongers, F. 1998. Ontogenetic changes in size, allometry, and mechanical design for tropical rain forest trees. American Journal of Botany 85: 266-272.

Valladares, F.; Wright, S.J.; Lasso, E.; Kitajima, K. \& Pearcy, R.W. 2000. Plastic phenotypic response to light of 16 congeneric shrubs from a Panamanian rainforest. Ecology 81: 1925-1936.

Valladares, F. \& Niinemets, U. 2008. Shade tolerance, a key plant feature of complex nature and consequences. The Annual Review of Ecology, Evolution, and Systematics 39: 237-257.

Veanello, R.B. \& Alvez, A.R. 1991. Metereologia básica e aplicações. Viçosa, Universidade Federal de Viçosa.

Weiner, J. \& Thomas, S.C., 1986. Size variability and competition in plant monocultures. Oikos 47: 211-222.

Zar, J.H. 1996. Biostatistical analysis. London, Prentice Hall. 